\title{
COMPARISON OF THE FORMATION AND DEVELOPMENT OF CAVITATION DAMAGE ON CAST AND SINTERED SAMPLES BASED ON BASALT
}

\author{
M. Pavlović1, M. Dojčinović1, Lj. Andrić2\#, D. Radulović² \\ 1 University of Belgrade, Faculty of Technology and Metallurgy, Karnegijeva 4, 11000 Belgrade, Serbia \\ 2Institute for Technology of Nuclear and Other Mineral Raw Materials, \\ Franchetd'Esperey 86, 11000 Belgrade, Serbia
}

(Received: September 10, 2019; Accepted: November 5, 2019)

\begin{abstract}
The paper examines the resistance to the effect of cavitation of glass-ceramics based on basalt. Two types of samples were investigated: cast and sintered samples based on basalt. The cavitation erosion test was performed using the ultrasonic vibratory method with a stationary sample. To measure the cavitation resistance, a change in sample mass in function of the cavitation time was monitored. The change in the morphology of the surface with the test time was followed by scanning electron microscopy. The level of the surface degradation of the samples was quantified using the image analysis. Samples were tested under the same conditions. A comparison of the properties of the resistance to the effect of cavitation was performed in relation to the calculated cavitation rates. The results showed the high degree of cavitation resistance of the tested samples and the possibility of their application in conditions of high cavitation loads.
\end{abstract}

Key words: Basalt; Cavitation damage; Cavitation resistance; Mass loss; Image analysis.

\section{Introduction}

The starting material for obtaining glassceramic samples was the olivine-pyroxene basalt from the Vrelo-Kopaonik deposit. Basalt is a cheap and wide spread raw material, which by sintering, melting and a certain cooling treatment can be used for the production of glass and glass ceramics with specific mechanical properties, high strength and low abrasivness [1-3]. It is also used for synthesis of new materials and products such as basalt wool, basalt fibers, armature, composite materials, which are used for the production of parts and equipment in the machinery industry, automotive industry, shipbuilding [4-9]. Good technical properties allow the use of basalt in civil engineering, for production of aggregate for modern road and rail shroud [10, 11], glaze for decoration of various ceramic [12], for making decorative furniture, dishes [10]. As an architectural construction stone, it is used for coating external and internal surfaces, for the production of floor coverings in production facilities and halls, for all types of hydrotechnical works [13]. The basalt rock processing technology is enviromentally clean and the products obtained by basalt technology are not carcinogenic [14]. The properties and microstructural characteristics of the obtained basalt products are determined depending on the conditions of their application [5].

In order to assess the possibility of using basalt in conditions of high temperatures and pressures, wear, aggressive of suspensions and liquids, corrosion, cavitation resistance of basalt samples has been investigated. Cavitation is a phenomenon of the formation, growth and implosion of steam or vapor gas bubbles in the flowing fluid [15]. Implosions of the cavitation bubbles create shock waves and micro-jets that damage the solid materials in contact with the flowing fluid. The formation and development of damage to the surface of the materials depends on numerous

\#Corresponding author: li.andric@itnms.ac.rs

doi: 10.5937/JMMA1901037P 
parameters. In the literature there are numerous results of the investigation of the occurrence of damage to materials caused by cavitation [16-20]. The structure and properties of the material (above all the hardness and strength of the material) as well as hydrodynamic parameters of the cavitation process show the great influence on material resistance under cavitation conditions [21-25]. The cavitation bubbles that implode to the surface of the material causes its elastic, plastic deformation or destruction that represents cavitation erosion with mass loss of material. During cavitation due to the colapse of the bubbles local high temperatures and pressures occur in a very short time interval [17]. Testing of material resistance to the effect of cavitation in practice is usually carried out in laboratory conditions using an ultrasonic vibratory cavitation test method (with a stationary sample) according to the ASTM G32 standard [26]. Most of the literature data relate to the use of metallic materials in cavitation conditions, primarily on the use of highly alloyed steels [17, 24]. In the last decade, the use of ceramic materials for the production of equipment components for work under such conditions has begun [18-23]. Ceramic materials in principle have less resistance to the effect of cavitation than metallic materials, but they also have the advantage of their high corrosion resistance properties [21].

The paper examines the resistance to the effect of cavitation of glass-ceramic samples based on basalt obtained by the sintering processes (sintered basalt samples) and processes of melting and casting with thermal treatment (cast basalt samples). During the cavitation erosion test, the mass loss of samples was measured. The formation and development of damage to the surface of the samples was followed by the image analysis using Image Pro Plus software program [27-30].

\section{Experimental Procedure}

\subsection{Materials}

The basic properties of basalt, which influenced its choice for exploring cavitation resistance and assessing the possibilities of application in engineering practice were: density 2460-2960 $\mathrm{kg} / \mathrm{m}^{3}$; melting point $1300-1400{ }^{\circ} \mathrm{C}$; high hardness 6.5-7 Mosh scale; compressive strength $80 \mathrm{MPa}$; porosity $3.78 \%$; hygroscopicity $1-4 \%$; moisture content $1.2 \%$; high resistance to frost; wear resistance; high resistance to acids, alkalis and heat; ecological and hygienic quality $[1,4,5,11]$. The samples of cast basalt (label: $\mathrm{CB}$ ) were obtained by melting the basalt aggregate at the temperature $1250^{\circ} \mathrm{C}$ and casting into sand molds. For the purpose of reducing stress, the casting are thermally treated at $890^{\circ} \mathrm{C} / 2 \mathrm{~h}$ [29]. The sintered basalt samples (label: SB) were obtained by pressing the basalt powder of $20 \mu \mathrm{m}$ grain size at the Leitz press under pressure of $1 \mathrm{MPa}$ and sintering at $1150{ }^{\circ} \mathrm{C} / 2 \mathrm{~h}$ [30]. The dimensions of samples $C B$ and $S B$ were: $(15 \times 15 \times 15) \mathrm{mm}$.

\subsection{Methods}

An ultrasonic vibratory method (with a stationary sample) was used to test cavitation resistance according to the standard ASTM G32 [26] and the procedure described in earlier works [17, 24]. The testing device consisted of a $360 \mathrm{~W}$ high frequency generator, electrostrictive transducer, transformer for mechanical vibrations and a water bath containing the test specimen. Cavitation erosion testing was accomplished utilizing the recommended standard values: frequency of vibration: $20 \pm 0.2 \mathrm{kHz}$; amplitude of vibrations at the top of the transformer: $50 \mu \mathrm{m}$; gap between the test specimen and the transformer: $0.5 \mathrm{~mm}$; temperature of the water bath: $25 \pm 1{ }^{\circ} \mathrm{C}$; water flow $5-10 \mathrm{ml} / \mathrm{s}$.

The ultrasonic vibration method with a stationary sample for cavitation is used when working with brittle specimen which cannot be threaded. The standard does not prescribe the dimensions of the specimen made from brittle materials. In this case, the specimen was fixed during the cavitation test with holders located at the bottom of the water bath. Below the head of the vibration concentrator surface and the stationary 
test sample, a strong cavitation zone is formed. Water in the water bath cools the sample and keeps its temperature constant. According with ASTM G32, three test specimens of basalt were used for the cavitation test and an average value of the measurements was taken as results for diagram which shows the relation between the mass loss of samples and testing time. According to ASTM G32, cavitation rate of the test material was calculated as the total mass loss of the sample after the total testing time. Selected sampling time (min) was: 15; 30; 60; 120. After each test interval, it was measured the change of the mass of sample by the analytical weighing accuracy of $0.1 \mathrm{mg}$. For the purpose of analyzing the surface changes under cavitation, the samples were photographed before, during and at the end of the test.

The morphology of the damaged surfaces was analyzed by a scanning electron microscopy (SEM) Joel JSM 6610 LV. Software sample analysis was performed in Image Pro Plus 6.0 [28]. The results of the analysis enabled the examination of the mechanisms of destruction of the surface of the samples by monitoring the following indicators of damage during the testing time of the cavitation process: the level of degradation of the sample surface, (P/P0, \%, where $\mathrm{P} 0$ refers to the reference surface without damage, and the value $P$ represents damage on the surface of the sample formed during the test), the number of formed individual pits, $\mathrm{Np}$ and average area of formed pits, Pav, $\mathrm{mm}^{2}$. Image Pro Plus allows access to some lines of profiles that are used to analyze the level of degradation of the sample surface $[27,28]$.The assessment of the behavior of the tested samples on the effect of cavitation was analyzed on the basis of the correlation of the obtained test results with the structure and properties of basalt. All obtained results of damage to the surface of the samples at the time of the cavitation activity are illustrated by the diagrams.

\section{Results and discussion}

The chemical composition of basalt rocks from the Vrelo-Kopaonik deposit to obtain samples of cast basalt (CB) and sintered basalt (SB) was: $56.21 \% \mathrm{SiO}_{2} ; 18.61 \% \mathrm{Al}_{2} \mathrm{O}_{3} ; 1.15 \% \mathrm{Fe}_{2} \mathrm{O}_{3} ; 2.97 \%$ $\mathrm{FeO} ; 3.40 \% \mathrm{MgO} ; 7.78 \% \quad \mathrm{CaO} ; 4.73 \% \quad \mathrm{Na}_{2} \mathrm{O}$; $3.37 \% \mathrm{~K}_{2} \mathrm{O} ; 1.11 \% \mathrm{TiO}_{2}$. The basic minerals of the basalt rock are: plagioclase, pyroxene and olivine.

Figure 1 shows the SEM microphotographs of obtained samples of basalt $C B$ and $S B$ before testing for the effect of cavitation.

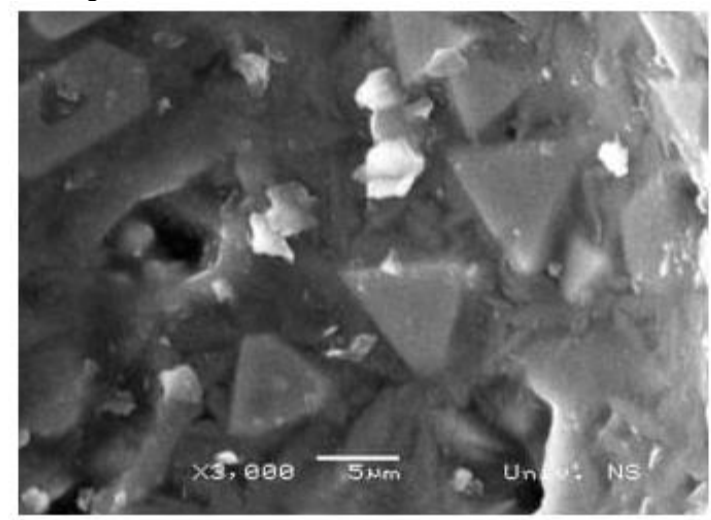

a)

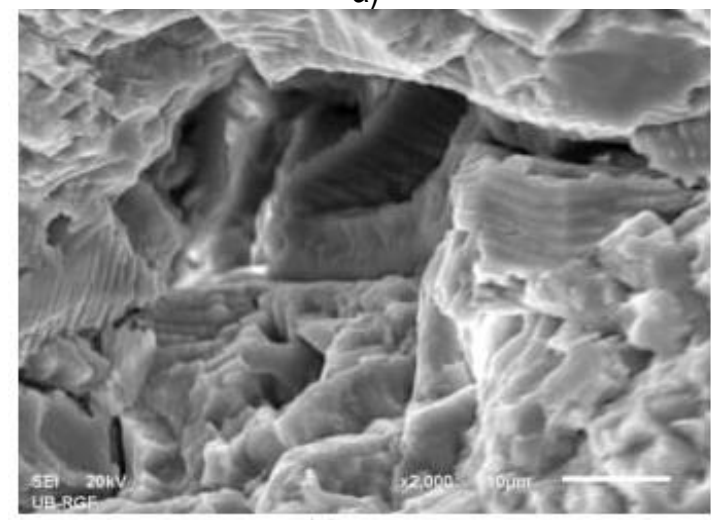

b)

Figure 1. SEM microphotographs of samples before cavitation test: a) cast basalt (CB); b) sintered basalt (SB)

The structure of the $C B$ sample is inhomogeneous with the appearance of various aggregates, among which a clear border is seen, Figure 1.a). The most common minerals are pyroxene, than plagioclases and smaller olivines. Some crystals in a glass base are thermally altered. A small number of bubbles incorporated in basalt are present. They are filled with air or glass. Figure 1.b) shows the structure of SB sample. The 
present plagioclase and pyroxene crystals are evenly distributed in the base mass. Also, the present gas bubbles are incorporated into the glass base of the basalt. Bubbles on the surface cause surface roughness and the appearance of pits. This all reduced the properties of the resistance of the samples to the effect of cavitation. During the cavitation test, the changes of the present bubbles contained in the base of basalt, as well as the present pits on the surface of the $C B$ and $S B$ samples, were monitored.

Measurement of the mass loss of the samples under the cavitation during the test time is shown in Figure 2.

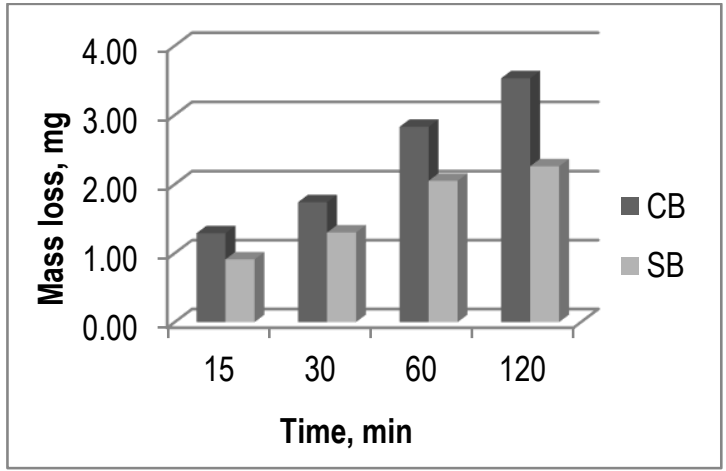

Figure 2. Mass loss of $C B$ and $S B$ basalt samples during the cavitation test

CB samples have a small mass loss, in first 15 min the mass loss was $1.29 \mathrm{mg}$ and slightly increased to a mass loss of $3.53 \mathrm{mg}$ for $120 \mathrm{~min}$ exposure. The cavitation rate for the $C B$ samples was $0.03 \mathrm{mg} / \mathrm{min}$. For samples SB, mass loss was also small, in first $15 \mathrm{~min}$ it was $0.91 \mathrm{mg}$ and slightly increased to $2.26 \mathrm{mg}$ in $120 \mathrm{~min}$ exposure. Cavitation rate for $\mathrm{SB}$ samples was $0.02 \mathrm{mg} / \mathrm{min}$. The results show that samples $C B$ and SB have high resistance to the effect of cavitation.

CB and SB basalt samples were photographed before and during the cavitation erosion test. Figure 3 shows photographs of $\mathrm{CB}$ and $\mathrm{SB}$ samples at the end of the cavitation test, for 120 min exposure with corresponding profile lines obtained using Image Pro Plus softver program [28].
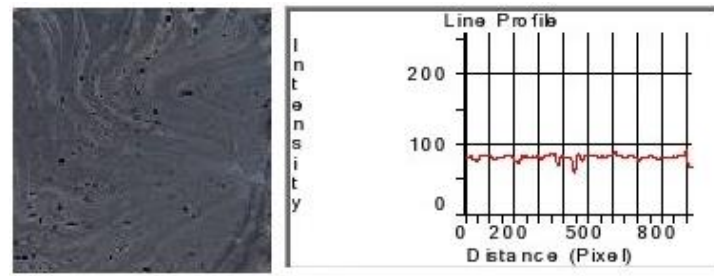

a) CB sample
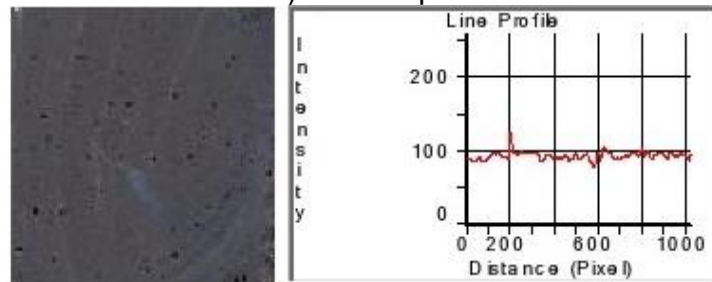

b) SB sample

Figure 3. Photographs of $C B$ and $S B$ samples at the end of the cavitation test after implementation of red filter and corresponding line profiles

From the Figure 3 it can be seen that samples $\mathrm{CB}$ and $\mathrm{SB}$ show small changes on the surface, with the appearance of small pits that appear near the bubbles and do not damage a significant surface area. The profile lines of the samples are uniform, and individual peaks, which are present at the same locations on the surface of the sample refered presence of individual pits, caused by the presence of bubbles in the structure, which were identified prior to the start of the test. This correspond to the results of a software image analysis obtained using Image Pro Plus, shown in Figures 4-6.

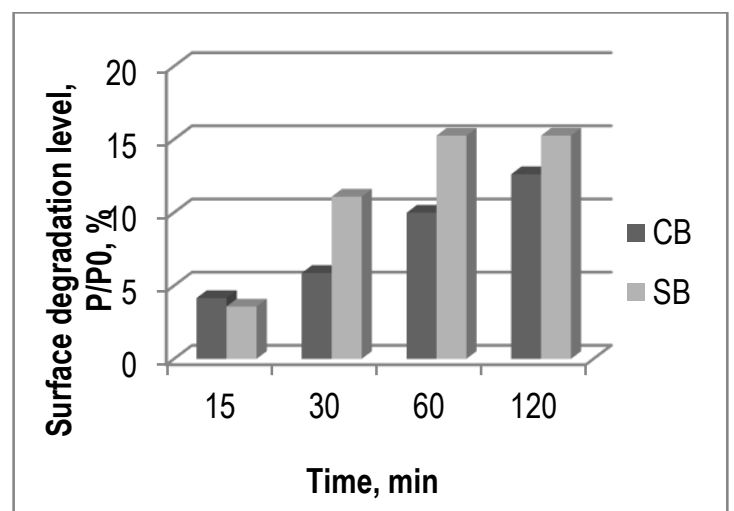

Figure 4. Surface degradation level for $C B$ and $S B$ basalt samples during the cavitation test 
Figure 4 shows the formation and development of the surface damage of basalt samples under the effect of cavitation. On the surface of $C B$ basalt samples in the first $30 \mathrm{~min}$ exposure, a large number of small pits are formed during the exposure. The surface damage mechanism is carried out by continuous creation and joining of small pits, Figure 5 . This is in accordance with the gradual increase in the value of the average area of formed pits, Figure 6 . The surface damage occurs at a low speed so that at the end of the test, after $120 \mathrm{~min}$ the level of surface damage was $12 \%$, Figure 4.

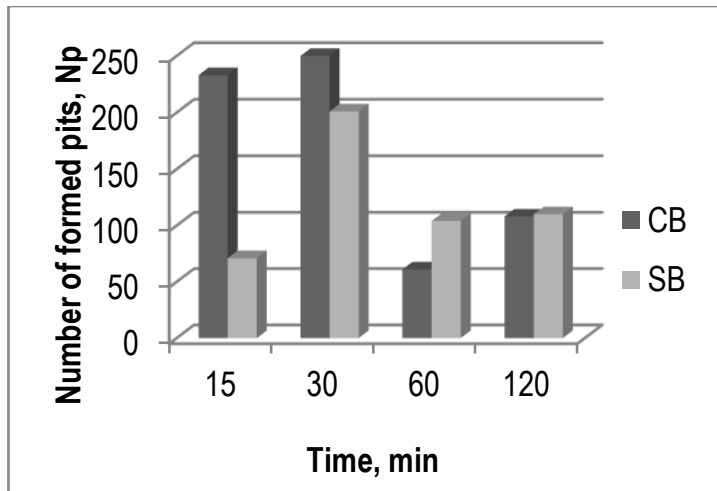

Figure 5. Number of formed pits for $C B$ and $S B$ basalt samples during the cavitation test

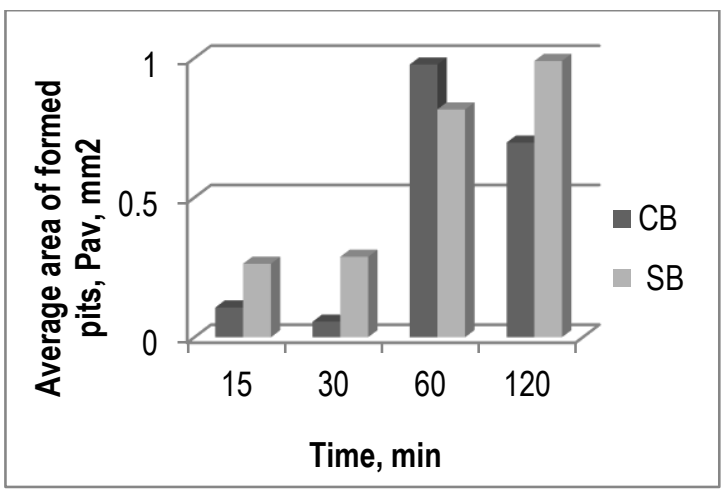

Figure 6. Average area of formed pits for $\mathrm{CB}$ and $\mathrm{SB}$ basalt samples during the cavitation test

Under the effect of cavitation on the surface of SB basalt samples, a greater number of pits were generated in the first $30 \mathrm{~min}$ of exposure. By the further effect of cavitation, the created pits are joined, Figure 5. In this case, the average area of the formed pits grows, Figure 6, which corresponds to an increase in the level of surface damage up to $15 \%$, Figure 4 .

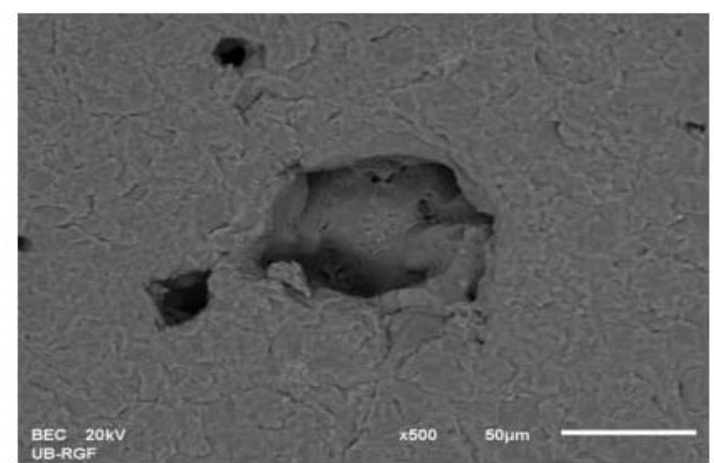

a) CB sample, $30 \mathrm{~min}$

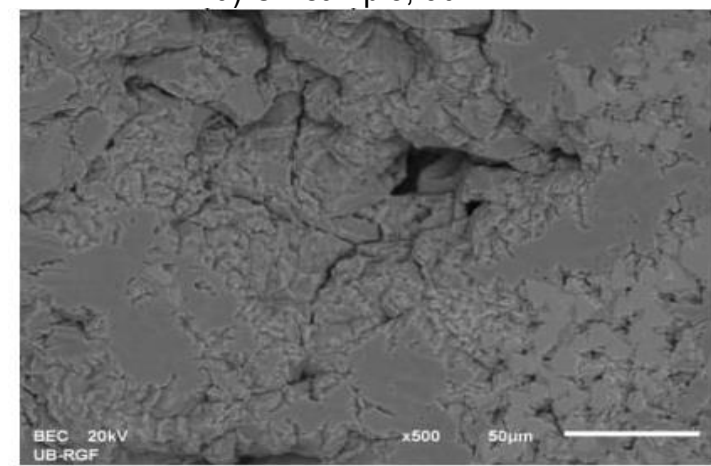

b) SB sample, $30 \mathrm{~min}$

Figure 7. SEM microphotographs of $C B$ and $S B$ basalt samples for 30 min exposure

On the surface of the samples near the gas bubbles, the small pits appear after $30 \mathrm{~min}$ exposure, Figure 7. Gas bubbles increase the roughness of the surface of the samples and contribute to the development of the cavitation damage. With increase in the cavitation time of 30 to $60 \mathrm{~min}$, the formed pits have changed very little in shape and size. This corresponds also to a small mass loss of the samples, shown in Figure 2. With both samples it was found that, with an increase in exposure to $120 \mathrm{~min}$, erosion of the surface of pits formed near gas bubbles occurs, Figure 8. This increase surface damage up to $12 \%$ for CB samples, or up to $15 \%$ for SB samples, shown in Figure 8. 


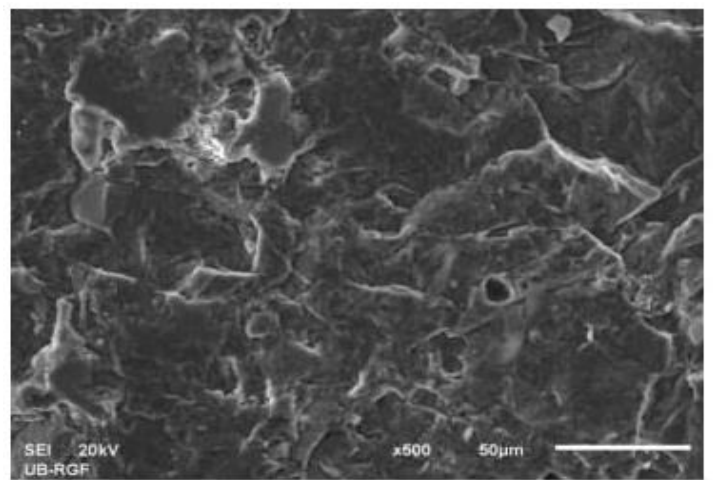

a) CB sample, $120 \mathrm{~min}$

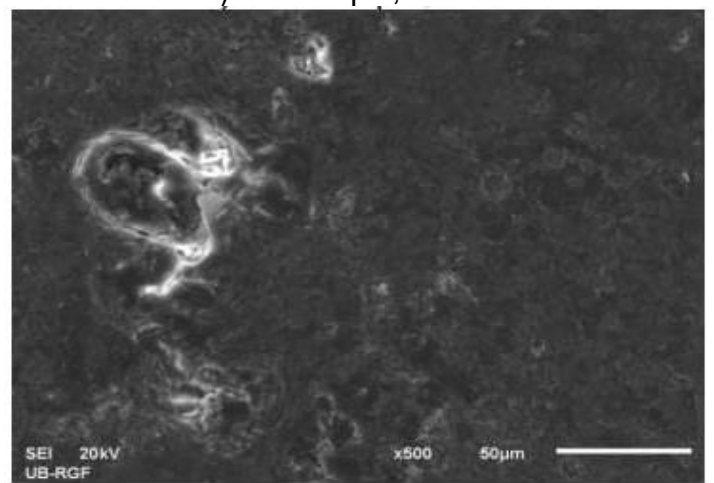

b) SB sample, $120 \mathrm{~min}$

Figure 8. SEM microphotographs of $C B$ and $S B$ basalt samples for 120 min exposure

\section{Conclusion}

Experimental investigations have shown that the synthesis of basalt based glass-ceramic samples have a great influence on cavitation resistance, especially relaxation cooling processes that eliminate internal stresses and reduce sample brittleness. The compact, uniform structure of the samples, without the presence of gas bubbles, contributes to increasing the resistance of the samples under the effect of cavitation. The results of the cavitation resistance test of the cast and sintered basalt samples showed a small mass loss (mg): 3.53 and 2.26, as well as small cavitation rates $(\mathrm{mg} / \mathrm{min}): 0.03$ and 0.02 , respectively. The tested samples showed a high resistance to the effect of cavitation and can be applies in conditions where high cavitation loads are expected.

\section{Acknowledgements}

The present research was financed by the Ministry of Education, Science and Technological Development of the Republic of Serbia as part of projects TR 35002 and 34006 for which the authors are grateful.

\section{Reference list:}

[1] Karamanov A., Ergul S., Afyildiz M., Pelino. (2008) Sinter- crystallization of a glass obtained from basaltic tuffs. Journal of NonCrystalline Solids, 354, 290-295.

[2] Yılmaz, S., Bayrak, G., Sen, S., Sen, U. (2006) Structural characterization of basaltbased glass-ceamic coatings. Materials \& Design, 27, 1092-1096.

[3] Cocić, M., Logar, M., Matović, B., PoharcLogar, V. (2010) Glass-Ceramics Obtained by the Cristallyzation of Basalt. Science of Sintering, 42, 383-388

[4] Barth, T. F. W. (1962) Theoretical petrology. John Wiley and Sons Inc., New Jork, USA, p. 387.

[5] Beall, G. H., Rittler, H. I. (1976) Basalt glass ceramics. Am. Ceram. Soc. Bull. 55, 579-82. ISBN ISSN 0002-7812.

[6] Prstic, A., Aćimovic, Z., Cosic, M., Andric, Lj., Tanasković, Z. (2005) Application of casting materials based basalt ore in metallurgy and mining industry. XI Balkan Mineral Processing Congress, Tirana, Albania, $422-425$.

[7] Prstić, A., Simić, R., Andrić, Lj., Acimovic, Z. (2003) Melting and casting of basalt ore. Mineral Processing in 21st Century - X Balkan Mineral Processing Congress, Varna, Bulgaria, 893-897.

[8] Todic, A., Nedeljkovic, B., Cikara, D., Ristovic, I. (2011) Particulate basalt-polymer composites investigation, Materials \& Design 32, 1677-1683.

[9] Fiore, V., Di Bella, G., Valenza, A. (2011) Glass-basalt/epoxy hybrid composites for marine applications, Materials \& Design, 32 , 2091-9. 
[10] Pavlović, M., Đuričić, M., Mumđić, A. (2015) Basalt application prospects for touristic facilities furnishing. Conference SED 2015, Uzice, Serbia, 53-60.

[11] Pavlović, M., Sarvan, M., Klisura, F., Aćimović, Z. (2016) Basalt- Raw Material for Production of Aggregate for Modern Road and Rail Shourd. 4th Conference Maintenace 2016, Zenica, B\&H, 175-183.

[12] Andrić, Lj., Aćimović, Z., Trumić, M., Prstić, A., Tanasković, Z. (2012) Specific characteristics of coating glazes based on basalt, Materials \& Design, 33, 9-13. doi: 10.1016/j.matdes.2012.02.022.

[13] Simic, R., Prstic, A., Gilic, N. (2002) Technical and economicalbase for building capacities for obtained casting products from basalt ore in Serbia. Conference - Cement 2002, Struga, Macedonia, 156-160.

[14] Čikara, D., Bajić, N., Rakin, M., Čikara-Anić, D. (2006) Basalt fibers-ecological alternative for glass fibers. XIV International Scientific and Professional Meeting, Eco-lst '10, Soko Banja, Serbia, 194-198.

[15] Franc, J. P., Michel, J. M. (2004) Fundamentals of cavitation.Series Fluid Mechanics and Its Applications, 76, XXII, Kluwer Academic Publischers, New York, Boston, Dordrecht, London, Moscow, p.306.

[16] Jasionwski, R., Pedzich, Z., Darius Z., W. Przetakiewicz, W. (2015) Cavitation Erosion Resistance of FeAl Intermetalics Alloys and $\mathrm{Al}_{2} \mathrm{O}_{3}$ - based Ceramics. Archives of Metallurgy and Materials 60 (2), 671-675.

[17] Dojčinović, M. (2013) Rougness measurement as an alternative method in evaluation of cavitation resistance of steel. Chem. Ind., 67, (2), 323-330.

[18] Garcia-Atance Fatjao, G., Hadfield, M., Vieillard, C., Sekulic, J. (2009) Early stage cavitation erosion within ceramics - An experimental investigation. Ceramic International, 35, (8), 3301-3312.

[19] Tomlinson, W. J., Matthews, S. J. (1994) Cavitation erosion of structural ceramics,
Ceramic International, 20, (3), 201-209.

[20] Litzow, U., Zum Gahr, K. H., Schneider, J. (2006) Cavitation erosion of advanced ceramics in water. International Journal of Materials Research, 97, 10, 1372-1377. doi: 10.3139/146.101380.

[21] Niebuhr, D: (2007) Cavitation erosion behavior of ceramic in aqueous solution. Wear, 263, (1-6), 295-300.

[22] Dular, M., Bachert, B., Stofferl, B., Širok, B. (2004) Relationship beetwen cavitation structures and cavitation damage. Wear, 257, 1176-1184.

[23] Dular, M., Osterman, A. (2016) Pit clustering in cavitation erosion, Wear, 265, 811-820.

[24] Aleksić, V., Dojčinović, M., Milović, Lj., Samardžić, I. (2016) Cavitation damages morphology of high-strength low- alloy steel, Metalurgija 55, 3, 423-425.

[25] Laguna-Camacho, J. R., Lewis, R., ViteTorres, M., Mendez-Mendez, J. V. (2013) A study of cavitation erosion on engineering materials. Wear, 301, (1-2), 467-476.

[26] Standard Method of Vibratory Cavitation Erosion Test, G32-92, Annual Book of ASTM Standards; ASTM: Philadelphia, PA, USA, 1992; Volume 03.02.

[27] Alturki, A F., Abouel-Kasem, A., Ahmed, S. M. (2012) Characteristics of Cavitation Erosion Using Image Processing Techniques, Journal of Tribology, 135 (1), 014502, No: TRIB-11056.

[28] Image Pro Plus 6.0, The Proven Solution for Image Analysis, Media Cybernetics: Rockville, MD, USA, 1993.

[29] Pavlovic, M., Dojčinovic, M., ProkicCvetkovic, R., Andric, Lj., Ceganjac, Z., Trumbulovic, Lj. (2019) Cavitation wear of Basalt Glass Ceramic, Materials, 12, 1552. doi: 10.3390/mai12091552.

[30] Pavlović, M. Dojčinović, M., Prokić-Cvetković, R., Andrić, Lj. (2019) The Mechanisms of Cavitation Erosion of Raw and Sintered Basalt. Science of Sintering, 4th volume (in press). 


\title{
POREĐENJE NASTAJANJA I RAZVOJA KAVITACIONIH OŠTEĆENJA LIVENIH I SINTEROVANIH UZORAKA NA BAZI BAZALTA
}

\author{
M. Pavlović1, M. Dojčinović1, Lj. Andrić"\#, D. Radulović² \\ 1University of Belgrade, Faculty of Technology and Metallurgy, \\ Karnegijeva 4, 11000 Belgrade, Serbia \\ 2Institute for Technology of Nuclear and Other Mineral Raw Materials, \\ Franchetd'Esperey 86, 11000 Belgrade, Serbia
}

(Primljen: 10. Septembar 2019.; Prihvaćen: 5. Novembar 2019.)

\begin{abstract}
Izvod
U radu je ispitivana otpornost na dejstvo kavitacije staklo-keramike na bazi bazalta. Ispitivane su dve vrste uzoraka: liveni $i$ sinterovani uzorci na bazi bazalta. Kavitaciono erozioni test izveden je pomoću ultrazvučne vibracione metode sa stacionarnim uzorkom. Da bi se odredila kavitaciona otpornost praćena je promena mase uzoraka u funkciji vremena ispitivanja. Promena morfologije oštećenja površine uzoraka tokom ispitivanja praćena je skenirajućom elektronskom mikroskopijom. Nivo degradacije površine kvantifikovan je korišćenjem analize slike. Uzorci su ispitivani pod istim uslovima. Poređenje svojstava otpornosti na dejstvo kavitacije izvršeno je u odnosu na vrednosti kavitacionih brzina. Rezultati su pokazali visok stepen otpornosti ispitivanih uzoraka i mogućnost njihove primene u uslovima visokih kavitacionih opterećenja.
\end{abstract}

Ključne reči: Bazalt; Kavitaciono oštećenje; Kavitaciona otpornost; Gubitak mase; Analiza slike. 